https://doi.org/10.19195/0137-1150.173.32

Data przesłania artykułu: 2.10 .2019

Data akceptacji artykułu: 27.01.2020

\author{
EDUARD BURGET
}

Ústav pro českou literaturu AV ČR, Praga, Czechy

\title{
Role historické paměti v románech Viléma Hejla
}

1.

V květnu 1968 se spisovatel Vilém Hejl (1934-1989) stal tiskovým tajemníkem klubu K 231, který sdružoval bývalé politické vězně padesátých let v Československu. Jeho účast v klubu ale neměla dlouhé trvání, nebot' samotný př́pravný výbor zanikl již krátce po srpnové okupaci vojsky Varšavské smlouvy začátkem zář́ 1968 poté, co ministerstvo vnitra neschválilo předložené stanovy ${ }^{1}$.

Vilém Hejl měl pro práci tiskového tajemníka K 231 nezbytné předpoklady: ve svých devatenácti letech byl v roce 1953 odsouzen $\mathrm{k}$ ročnímu nepodmíněnému trestu společně s několika svými vrstevníky z pražského Drtinova gymnázia v rámci akce Šeřík. Vykonstruované obvinění proti Hejlovi a jeho přátelům se opíralo o § 79 trestního zákona č. 86/1950 Sb. (nedovolené sdružování proti republice), přičemž celá skupina byla souzena pro snahy, jež měly směřovat k obnově skautské organizace Junák ${ }^{2}$. Jelikož $\mathrm{k}$ zatčení došlo bezprostředně po maturitě, Hejlovi bylo znemožněno studium na vysoké škole, kde uvažoval o studiu práv, historie a filozofie. Po propuštění z vězení poté pracoval jako občan „druhé kategorie“ $v$ různých technických profesích a teprve počátkem šedesátých let se začal soustavněji prosazovat s vlastní literární tvorbou. Nejprve psal rozhlasové hry ${ }^{3}$

${ }^{1}$ P. Blažek et al., Aby se to už neopakovalo. Katalog $k$ výstavě o dějinách sdružení bývalých politických vězňů K 231, ÚSTR - K 231 - Sdružení bývalých politických vězňů, Praha 2008, s. $59-60$.

2 Archiv bezpečnostních složek (dále: ABS), fond Svazky kontrarozvědného rozpracování, a. č. 675 MV, Akce Šeřik. Podrobněji k Hejlovu věznění E. Burget, Zásada sporu Viléma Hejla, „Marginalia Historica“ 7, 2016, č. 1, s. 39-53.

${ }^{3} \mathrm{~V}$ archivu Českého rozhlasu se dochovaly pouze tři záznamy rozhlasových her: detektivní př́iběh Zlatý drak natočil režisér Otakar Bílek v roce 1964, dramatizaci Sebraných zločinů Vladimíra Hudce připravil v roce 1967 režisér Jiří Valchař a hra Trochu málo na ságu měla premiéru v lednu 
a externě spolupracoval s Krátkým filmem, pro který vytvořil přes šedesát scénářù $\mathrm{k}$ dokumentárním, populárně naučným či propagačním snímkům ${ }^{4}$. Příležitostně se snažil i překládat, nejčastěji z polštiny, angličtiny a ruštiny. V roce 1961 dopsal první samostatnou prózu Slavobrána, kterou nabídl Krajskému nakladatelství v Českých Budějovicích. Kniha, jež prošla pozitivním lektorským posouzením, ale nakonec vydána nebyla. Místo Slavobrány však v Českých Budějovicích autorovi vydali dvoudílný satirický román s detektivní zápletkou Sebrané zločiny Vladimíra Hudce (1965 a 1966), který během krátké doby získal takovou čtenářskou popularitu, že se jeho první díl rozhodl zfilmovat režisér Martin Frič; celovečerní film vstoupil do kin v závěru roku 1967 pod názvem Př́sně tajné premiéry ${ }^{5}$. Jako prozaik si Vilém Hejl během šedesátých let vybudoval poměrně slušné postavení, navíc jeho zájem o věci veřejné, politiku, historii, problematiku soudních rehabilitací a vlastní vězeňskou minulost jej víceméně předurčovaly $\mathrm{k}$ tomu, aby byl v době obrodného procesu pražské jara 1968 osloven klubem K 231 s nabídkou spolupráce.

Od samého počátku svého působení v K 231 začal Hejl pracovat v dokumentační komisi na prrípravě „Bílé knihy K 231“, která měla zmapovat zločiny proti

1968 rovněž v režii Jiř́iho Valchaře. U ostatních Hejlových her se zvukový záznam nedochoval ( $V$ suterénu neni telefon, Univerzita pro milence, Plášt svaté Kateřiny a Poslední z Nibelungů $\mathrm{k}$ této hře se $\mathrm{v}$ archivu Českého rozhlasu dochoval pouze scénář a údaj o zařazení do vysílání dne 20. června 1965). V pozůstalosti Viléma Hejla, která je dnes uložena v Literárním archivu Památníku národního písemnictví v Praze (dále: LA PNP), najdeme několik autorových dosud nevydaných literárních textů, zejména cyklus čtyř próz Procesy po setměni (Přeličení za zavřenými dveřmi, Zmatečni př́ipad, Návrat nežádoucí a Dvojník) či novelu Slavobrána. Některé z těchto textů Hejl zároveň zpracoval do podoby rozhlasových her, mimo jiné novela Zmateční př́pad tematicky souzní s rozhlasovou hrou Trochu málo na ságu, ve které autor řešil problematiku soudních rehabilitací bývalých politických vězňů komunistického režimu. Srov. LA PNP, fond Vilém Hejl, /nezprac./. Podrobněji k literárnímu životopisu autora viz: M. Zelinský, Vilém Hejl, [in:] Slovník české literatury po roce 1945, www.slovnikceskeliteratury.cz/showContent.jsp?docId=739\&hl=HEJL+ [citováno dne: 26.8.2019].

${ }^{4} \mathrm{~V}$ Hejlově literární pozůstalosti se nacházejí z těchto let mimo jiné scénáře a náměty $\mathrm{k}$ filmům o branných hrách mládeže, družstevní bytové výstavbě ve Vítkovicích, o Nové huti Klementa Gottwalda v Ostravě, Horním Slavkovu, dále propagační filmy pro podnik zahraničního obchodu Technoexport či ministerstvo zemědělství. Srov. LA PNP, fond Vilém Hejl, /nezprac./.

${ }^{5}$ V letech 1980-1981 Hejl svůj román o Vladimíru Hudcovi částečně přepracoval a nově připsal třetí díl nazvaný Park kultury. Kniha vyšla v celku poprvé až čtyři roky po autorově smrti, v roce 1993 v nakladatelství Marsyas. Srov. M. Petř́ček, Detektivka jako nástroj satiry, „Literární noviny“ 26, 1993, s. 7. Žánru detektivky se Hejl věnoval i v pozdějších letech, ještě před svým odchodem do exilu v roce 1977 napsal detektivku Připad zlatých vlajek, která však vyšla v edici Magnet pod jménem jeho prŕítele, právníka Svatopluka Zlámaného. V letech 1979 a 1984 pak vydala Mladá fronta v populární edici Smaragd dvě knihy detektivních povídek Hra na slepou bábu a Případ s černým vzadu, které opět svým jménem pokryl Svatopluk Zlámaný. V polovině sedmdesátých let Hejl také napsal, na přání kolegů a redaktora nakladatelství Mladá fronta Vojtěcha Kantora, po vzoru Škvoreckého Nápadů čtenárù detektivek vlastní esej Poznámky čtenáře českých detektivek, který vyšel nejprve v exilovém časopise „Proměny“ (1979) a v letech 1991 a 1992 na pokračování v časopise „Knokaut"“.

Slavica Wratislaviensia 173, 2020

(C) for this edition by CNS 
lidskosti spáchané po roce 1948 komunistickou justicí. Směle započaté plány na vydání knihy byly srpnem 1968 přerušeny. Mnozí bývalí političtí vězni odešli bezprostředně po srpnu 1968 do exilu, kde ve své činnosti pokračovali. V roce 1973 pak byla v exilu vydána Zpráva dokumentační komise $K$ 231, kterou na základě svědectví, jež političtí vězni zanechali ještě v Československu jako podklad pro své rehabilitační řízení, k vydání připravili Ota Rambousek a Ladislav Gruber, s doslovem Josefa Škvoreckého ${ }^{6}$.

Po svém odchodu do emigrace v roce 1978 se Vilém Hejl rozhodl na své dř́vější působení v K 231 navázat. Na podzim 1979 obeslal společně s Ivanem Medkem dopisem a dotazníkem české emigranty s žádostí o poskytnutí svědectví o praktikách Státní bezpečnosti v Československu. Původně měla práce vycházející z výpovědí bývalých vězňů komunistické justice vyjít $\mathrm{v}$ curyšském nakladatelství Konfrontace. Její vydání však bylo z různých důvodů opakovaně odkládáno ${ }^{7}$. Nakonec se knihy ujalo nakladatelství Sixty-Eight Publishers Zdeny Salivarové a Josefa Škvoreckého, kde Hejlova obsáhlá kniha Zpráva o organizovaném násili vyšla v roce 1986. V torontskému vydání byl jako spoluautor uveden vedle Hejla historik Karel Kaplan, který ovšem svou roli na vzniku knihy později označil za marginální. Podle jeho slov od něj vzešel pouze prvotní podnět ke zpracování tématu, Hejlovi předal podstatnou část své archivní dokumentace, avšak autorsky se na výsledném textu podílel jen minimálně ${ }^{8}$.

\section{2.}

Angažmá Viléma Hejla v klubu K 231, jeho práce na obsáhlé a ve své době nebývalé podrobné Zprávě o organizovaném násilí, kontakty s někdejšími politickými vězni a jejich mnohdy otřesná svědectví výrazně ovlivnila jeho prozaickou tvorbu pro nadcházející léta. Hejl po maturitě uvažoval o studiu historie, a ačkoliv se mu tento sen nepodařilo nikdy realizovat, historie se pro něj stala celoživotní zálibou, přičemž ve svých prózách opakovaně pracoval s různými historickými mýty a stereotypy. Fascinovalo jej, jak se pamět' (at' již kolektivní nebo individuální) spolupodílí na utváření dějin, jak jsou její soudy ošidné a dějiny, které píšeme, nejednoznačné a mnohdy i nespravedlivé.

Ještě před svým odchodem do exilu v roce 1978 se Hejlovi podařilo přes československé hranice propašovat rukopisy svých tř́ nových próz, které vznikly mezi lety 1969-1975 a které se doma opakovaně a neúspěšně pokoušel nabídnut k vydání. První z trojice románů Zásada sporu vyšel u Škvoreckých v roce 1979,

${ }^{6}$ O. Rambousek, L. Gruber, Zpráva dokumentační komise K 231, Toronto 1973.

7 V. Hejl, Doslov k nevydané knize, „Národní politika (Mnichov)“ 2, 1979, s. 1, 7; dále: ABS, fond I. správa SNB, a. č. 10081/482, Kopie dopisu Viléma Hejla a Ivana Medka z podzimu 1979.

8 K. Kaplan, Úvodní poznámka, [in:] V. Hejl, Zpráva o organizovaném násilí, Praha 1990, nestr. 
román Ex offo vydali o rok později rovněž v Sixty-Eight Publishers a ve stejném roce v curyšském nakladatelství Konfrontace vyšla i novela Hodina hvězdopravcü9.

Jednotícím prvkem všech tří próz je autorova tematizace paměti a její zakořenění v politicko-ideologických kontextech doby. Hejl, sám aktivní aktér politických proměn pražského jara roku 1968, v uvedených prozách sice pracuje s historíí, jeho texty však nelze označit za historické romány v pravém slova smyslu. Tématy jsou sice událostí minulých dob, nicméně autor minulé děje jednoznačně vztahuje ke své současnosti. Prózy Viléma Hejla byly částečně reflektovány v době svého vydání v exilovém prostředí, v Československu po roce 1989 oficiálně již nikdy nevyšly a je škoda, že jak autor, tak jeho prózy upadly téměř $\mathrm{v}$ zapomnění. Předkládaný př́spěvek se proto pokouší na základě literárně-historického i archivního výzkumu Hejlova klíčová prozaická díla včelnit zpět do kontextu české literatury a zasadit je zároveň do širšího rámce autorova života.

\section{3.}

Román Zásada sporu je koncipována jako fiktivní paměti reálné historické postavy, básníka Šimona Lomnického z Budče (1552-1623) a je zasazena do doby bezprostředně předcházející bitvě na Bílé hoře a v roce 1620 do událostí několika měsíců krátce po bitvě. Hlavní hrdina Šimon Lomnický stále pochybuje o svých literárních schopnostech, a přestože je katolík, drží alespoň zpočátku palce stavovskému povstání. Především se však zabývá myšlenkou napsání velkého hrdinského eposu, ve kterém by vylíčil soudobé události. Rád by napsal „českou Illiadu“, jež by popisovala hrdinské povstání českých stavů, jejich politickou prozíravost, čestnost i odvahu. Při promýšlení díla se však opakovaně potýká $\mathrm{s}$ nepřekonatelným problémem, který spočívá $\mathrm{v}$ pohledu autora, který politickým hráčům vidí až př́lišs do karet. Proto není schopen s čistým svědomím stvořit $\mathrm{z}$ vůdčích představitelů stavovského vojska hrdiny. Místo psaní Šimon o hrdinství přemýšlí, což jej nakonec dovede $\mathrm{k}$ jednoznačnému závěru: skutečný hrdina neexistuje, vše je jen záležitost mýtu. Teprve v okamžiku, kdy nebude naživu jediný pamětník či nepohodlný svědek, který by prozradil, jak to skutečně bylo, může vzniknout ideální hrdina ${ }^{10}$.

Román Zásada sporu byl v exilovém prostředí přivítán se značným uznáním, pro mnohé recenzenty byl též svým způsobem překvapivý, nebot' Hejla dosud vnímali jako autora knih lehčího žánru. Většina recenzentů se shodla, že autor se svým románem vyrovnává př́edevším s událostmi pražského jara 1968, kdy se rovněž mnozí „povstalci“ velmi rychle zorientovali v nepřehledném dění a po srpnové

9 Podle výpovědi redaktora Mladé fronty Vojtěcha Kantora nabídl Hejl postupně do nakladatelství rukopisy svých románů Zásada sporu (v roce 1970) a Hodina hvězdopravců (1972/1973). Oba prošly standardním lektorským řízením, jejich vydání však bylo odloženo na neurčito. Koncem roku 1975 poté Hejl nabídl Kantorovi rukopis románu Ex offo. Srov. ABS, fond Svazky kontrarozvědného rozpracování, a. č. 671575 MV, Informace o stavu profylakticko-rozkladného opatření v akci Sit', po provedení částečné dokumentace z 24. března 1976.

10 V. Hejl, Zásada sporu, Toronto 1979, s. 17. 
okupaci se přimkli k novému normalizačnímu režimu ${ }^{11}$. Hejl se však nestaví, na rozdíl od jiných, do role arbitra, nechce nikoho soudit, na př́iběhu Šimona Lomnického ukazuje nejednoznačnost dějin a problém člověka, který se při bližším pohledu na aktuální dění nemůže jednoduše ztotožnit $s$ tou či onou ideou či ideologií, př́padně bezvýhradně přijmout „politický program“ té či oné strany.

Druhý exilový román Ex offo Hejl pro změnu koncipoval jako detektivní př́iběh odehrávající se v Československu v době nastupující normalizace. Hlavní hrdina, Radim Jelínek, je bývalý novinář spjatý s obrodným procesem. Nyní se živí jako taxikář a soukromě vyšetřuje záhadnou smrt př́itele, který kdysi napsal článek o jedné zapomenuté epizodě z prusko-rakouské války v roce 1866 . V souvislosti se smrtí př́tele začne zkoumat i onu dávnou válečnou epizodu. Brzy zjistí, že výsledky bádání, které jeho mrtvý přítel před lety publikoval, neodpovídají historické skutečnosti, nebot’ hlavního aktéra historických událostí roku 1866 - učitele Marholta - nelze označit ani za hrdinu, ani za kolaboranta. Když se pak o své závěry podělí se svými práteli, je jimi odmítnut. Nikdo z nich — v rozporu s historickými fakty - Jelínkovu interpretaci událostí roku 1866 nepřijme. Jelínkův výklad o Marholtovi by v zásadě obhajoval postup, který používal normalizační režim proti reformistům roku 1968. Právě takové otázky, jež uvažovaly o relativnosti historických soudů, Hejla silně podněcovaly a opakovaně se k nim vracel. Naposledy ve své nejlepší próze, novele Hodina hvězdopravců z roku 1980.

\section{4.}

Hodinu hvězdopravců Hejl původně napsal v polovině sedmdesátých let jako rozhlasovou inscenaci odehrávající se pouze $\mathrm{v}$ jedné dějové rovině válečného roku $1943^{12}$. Jednou z hlavních postav př́běhu je vysoký důstojník SS Helmut

11 O románu napsali recenze do exilových periodik mimo jiné J. Dresler, Román o charakteru, „Národní politika (Mnichov)“ 10, 1979, s. 2; J. Strnad, Historia magistra vitae?, „Hlasy domova (Melbourne)“16, 1979, s. 7-8; A. Kratochvil, Renesance historického románu, „České slovo (Mnichov)“ 2, 1980, s. 7; J. Kovtun, Vilém Hejl, Zásada sporu, „Svědectví“ 61, 1980, s. 107-109. Jako originální variaci na kampanovské téma vnímal Zásadu sporu literární historik Vladimír Novotný v př́spěvku, který zazněl v roce 1996 na konferenci o Zikmundu Wintrovi. Srov. V. Novotný, Ke kontextům kampanovského tématu, [in:] Zikmund Winter mezi historií a uměním, ed. V. Brožová, Rakovník 1999, s. 168-178.

12 Před Vánoci roku 1975 rozhlasovou hru Hodina hvězdopravců odvysílal polský a poté i rakouský rozhlas. Podle záznamů StB zaslal scénáŕ Hodiny hvězdopravců do Polska standardní oficiální cestou Československý rozhlas, hru přeložil Hejlův přitel, spisovatel a překladatel Andrzej Piotrowski. Hra v Československu nebyla nikdy uvedena. Dvě české, německá a polská verze rozhlasové hry jsou uloženy v autorově osobním fondu. O problémech, které provázely uvedení v polském rozhlase, podal Vilém Hejl svědectví v rozhovoru, viz A. Jagodziński, Czułem się zbyt stary, aby nadal w kraju tracić czas... Rozmowa z Vilémem Hejlem, [in:] idem, Banici. Rozmowy z czeskimi pisarzami emigracyjnymi, Kraków 1988, s. 58-61. Dále též srov. LA PNP, fond Vilém Hejl, /nezprac./; ABS, fond Svazky kontrarozvědného rozpracování, a. č. 671575 MV, zpráva náčelníka odboru pro mezinárodní styky FMV plk. Josefa Vlčka z 9. srpna 1976 o zastoupení děl Viléma Hejla v Polsku. 
Kollinger, který byl po značnou část svého života zcela oddán nacistické ideo-logii. K podlomení jeho „víry“ v nacistický režim dojde v okamžiku, kdy byl pověřen úkolem potvrdit místo, kde je ukrýván fašistický vůdce Benito Mussolini, sesazený a uvězněný italským králem v červenci 1943. Tento úkol má však Kollinger, na prání vyšších míst, konkrétně Heinricha Himmlera, jenž má slabost pro okultismus, vyřešit za pomoci astrologů. Ti mají ale jen potvrdit, že zjištění německých tajných služeb o Mussoliniho internaci jsou pravdivá. Kollingerovi, který astrologií a okultními vědami pohrdá, se rázem zhroutí jeho dosavadní svět, nebot' se nedokáže smířit s představou, že nacistický režim nachází svou vnitřní jistotu v názorech několika šarlatánů, pro tento účel svezených z několika koncentračních táborů, jinými slovy, aby Himmler uvěřil tvrzení německých tajných služeb, potřebuje si jejich zjištění nechat ověřit astrology.

Pro knižní vydání Hejl text podstatně přepracoval a někdejší hru proměnil v novelu. Hodina hvězdopravců se nyní odehrává ve dvou časových rovinách. Ta první zůstala v zásadě stejná a zachycuje původní př́iběh válečného roku 1943, kdy bylo do vily ve Wansee pod Kollingerovým dohledem svezeno šest astrologů. Druhá dějová linie, pro nás podstatnější, se odehrává až po Kollingerově smrti dlouho po válce a jejím vypravěčem je německý lékař Otto Rümmele, který byl posledních několik let Kollingerovým osobním lékařem. Nutno poznamenat, že lékařem psychiatrem. Rümmele v druhé dějové linii vypráví Kollingerův př́íběh či svým způsobem píše jeho paměti na základě písemností, které Kollinger po sobě zanechal a lékař se stal správcem jeho pozůstalosti. Postupně tak před čtenáŕi odhaluje pravou Kolingerovu identitu a jeho zpočátku rezervovaný postoj, který ke Kollingerovi měl v době jeho života, se začíná pozvolna proměňovat v jistou podivnou formu zvláštního obdivu. Kollinger - slovy lékaře Rümmeleho - tento „zabiják s doktorátem“ jej začíná fascinovat. Lékařovy úvahy o roli jedince v soukolí dějin, o podstatě zla a dějinách 20 . století tak tvoří jakési svébytné komentáře $\mathrm{k}$ vlastnímu Kollingerovu prríběhu. Při pozorném čtení těchto úvah zde najdeme pasáže, jež se nepochybně opírají o autorovu prožitou zkušenost z období, kdy pracoval v K 231 a aktivně se účastnil událostí pražského jara. Lékaře Rümmeleho totiž v pravidelných intervalech navštěvují staří přátelé, jež mají za sebou často dlouholeté věznění z dob nacistické vlády. Jejich příběhy ale stárnoucího lékaře poněkud nudí, protože se od nich nedozví nic, co by sám neznal z vlastní zkušenosti. O to víc jej naopak zajímá Kollinger, který pro něj ztělesňuje naprosto odlišný svět, svět, který mu byl dosud utajen. Bývalý stoupenec nacismu je pravým opakem jeho i starých přátel: chladný, přitom vzdělaný a racionální zabiják, který byl i mnoho let po válce přesvědčen o blahodárnosti nacionálního socialismu. Rümmele, který krůček po krůčku vytváří Kollingerův psychologický profil, se ve svých komentárích velmi př́sně vyjadřuje o svých pacientech, bývalých i současných politicích, které nejenže s Kollingerem srovnává, ale v jejich načrtnutých portrétech poznáváme politické představitele pražského jara 1968: 
Co jsem si vyslechnul od nich je kryto povinnou lékařskou mlčenlivostí. Prozradím pouze, že mne vždy znovu překvapovalo, jak jsou tihle vlivní lidé v podstatě prost'áčkovsky omezení, že se vyznají toliko v taktických pravidlech své hry a vštípili si jenom svoje doktríny, kdežto o světě, který usilují pořádat, se stačili dozvědět jen málo, povrchně a neutříděně, a $\mathrm{z}$ toho mála pochopili doopravdy ještě méně. [...] Pokud budou př́ští historici zkoumat jenom jejich rozhodnutí a projekty, projevy a polemiky, porozumí našim časům asi jako autor učebnice zeměpisu, který by ji sepisoval podle prospektů cestovních kanceláří. ${ }^{13}$

Setkání s Kollingerem pak lékaře Rümmeleho nutí k přehodnocení svého dosavadního pohledu na nacistickou minulost. Neznamená to však, že by se snad lékař stal obdivovatelem nacistických politiků, spíše se mu rozpadl dosavadní černobílý obraz, který o nacionálním socialismu vytvořili pováleční historici, aniž by se hlouběji zamysleli nad podstatou zla a motivacemi jednotlivých aktéru totalitního systému. Kollinger totiž vůbec

nezapadal do obrazu, jaký jsem si o hnědém režimu tvořil z poválečných učebnic, z dokumentárních sborníků a konečně z nejednoho vlastního pozorování. Byl jsem do té doby přesvědčen, že Třetí říše a její vládnoucí strana stály a padaly s kandidáty existence, kteří se chytili politiky jako své poslední př́ležitosti. Spiknutí odmítnutých, spiknutí méněcenných, spiknutí vykořeněných, spiknutí osnované propadlým kvintánem z reálky v Linci, který toužil být akademickým malířem a jemuž však rostly hrozny př́liš vysoko, jenž ale dovedl strhnout neúspěšného literáta i ctižádostivého chovatele drůbeže, spojit $\mathrm{k}$ jednomu cíli pansky nadutého pilota bez armády s nezaměstnaným námořníkem [...]. Co mezi nimi čekal, co tam mohl hledat dr. phil. Helmut Kollinger? ${ }^{14}$

Kollingerův př́iběh, příběh člověka jiné generace, tak pozvolna proměňuje život o řadu let mladšího lékaře Rümmeleho, který si začne klást otázku, kde jsou hranice mezi minulostí a př́tomností, aby záhy zjistil, že takové hranice neexistují, nebot' minulost není mrtvá, ale naopak s prŕtomností i budoucností tvoří jeden nedělitelný celek.

Hlavní hrdina a vypravěč príběhu je postavou, do které autor, dle svých slov $\mathrm{v}$ rozhovoru proneseném po vydání knihy v rádiu Svobodná Evropa, koncentroval několik svých vrstevníků, se kterými se setkal v německém exilu. Ti žili ve svobodné společnosti a v podmínkách, kde člověk velmi rychle nabyde přesvědčení, že se ho minulost netýká a tedy, že se ho netýká ani dění v jiných totalitních režimech okolních států. Setkání Rümmeleho s Kollingerem je tak v Hejlově podání nemilosrdným setkáním s konkrétními dějinami, s živou pamětí, která v kombinaci s vlastní prožívanou prrítomností nevěstí pro budoucnost nic dobrého. Výsledkem tohoto poznání je pak strach, hluboký strach z budoucích věcí, kdy se chladný racionalismus Kollingerů, který však naše př́tomnost zploštuje a paušalizuje do podoby podivných anomálií, za určitých okolností může znovu spojit s diletantismem odmítnutých, méněcenných a vykořeněných, kteří slaboduché politiky př́tomnosti opět smetou svým radikalismem, oddaností nové ideologii a populismem. Rümmeleho život nebude po setkání s Kollingerem už nikdy jako dř́v.

13 V. Hejl, Hodina hvězdopravců, Curych 1980, s. 31.

14 Ibidem, s. 50. 
5.

Vilém Hejl se ve svých prózách stále vracel ke stejným otázkám: jaká je role jedince na pozadí velkých dějin, jak jsou dějiny nejednoznačné a nespravedlivé, jak je lidská pamět' snadno manipulovatelná. Přesto je třeba říci, že v Hejlově pohledu na dějiny je dosti podstatná dávka skepse a intelektuálního elitářství. Jak on sám, tak i jeho hrdinové si vždy chtěli zachovat určitý odstup od dění kolem sebe, udržet si nadhled, nejít s davem a nepodporovat tvorbu stereotypů a mýtů, jež slouží k prosazení politických zájmů kohokoliv. A takový byl do jisté míry i autor sám. Což nakonec vedlo $\mathrm{k}$ tomu, že se ani v exilu nesetkal vždy jen s kladným príijetím. Vytýkána mu byla jeho hyperkritičnost (v př́ípadě Hodiny hvězdopravců zesměšnění reformních politiků i bývalých politických věznnů žijících v exilu, které pasoval do role zpohodlnělých měštáků, kteří mezi sebou jen vzpomínají na někdejší dávná utrpení) a rovněž snahu provokovat. Přesto si dovolím Hejlovu poslední prózu označit za nadčasovou, nebot' otázky, které v ní autor klade, jsou silně aktuální i v dnešní době.

Při vzniku práce byly využity zdroje výzkumné infrastruktury Česká literární bibliografie (http://clb.ucl.cas.cz)

\section{Prameny}

Archiv bezpečnostních složek, fond I. správa SNB, a. č. 10081/482, Kopie dopisu Viléma Hejla a Ivana Medka z podzimu 1979.

Archiv bezpečnostních složek, fond Svazky kontrarozvědného rozpracování, a. č. 671575 MV, Informace o stavu profylakticko-rozkladného opatření v akci Sit', po provedení částečné dokumentace z 24. března 1976.

Archiv bezpečnostních složek, fond Svazky kontrarozvědného rozpracování, a. č. 671575 MV, zpráva náčelníka odboru pro mezinárodní styky FMV plk. Josefa Vlčka z 9. srpna 1976 o zastoupení děl Viléma Hejla v Polsku.

Archiv bezepečnostních složek, fond Svazky kontrarozvědného rozpracování, a. č. 675 MV, Akce Šřrik.

Literární archiv památníku národního písemnictví, fond Vilém Hejl, /nezprac./.

\section{Bibliografie}

Blažek P., Bursík T., Halla J., Hoppe J., Aby se to už neopakovalo. Katalog $k$ výstavě o dějinách sdružení bývalých politických vězňn K 231, ÚSTR - K 231 - Sdružení bývalých politických vězňủ, Praha 2008.

Burget E., Zásada sporu Viléma Hejla, „Marginalia Historica“ 7, 2016, č. 1.

Dresler J., Román o charakteru, „Národní politika (Mnichov)“ 10, 1979.

Hejl V., Doslov k nevydané knize, „Národní politika (Mnichov)“ 2, 1979.

Hejl V., Ex offo, Sixty-Eight Publishers, Toronto 1980.

Hejl V., Hodina hvězdopravců, Konfrontace, Curych 1980.

Hejl V., Zásada sporu, Sixty-Eight Publishers, Toronto 1979. 
Jagodziński A., Czułem się zbyt stary, aby nadal w kraju tracić czas... Rozmowa z Vilémem Hejlem, [in:] idem, Banici. Rozmowy z czeskimi pisarzami emigracyjnymi, Oficyna Literacka, Kraków 1988.

Kaplan K., Úvodní poznámka, [in:] V. Hejl, Zpráva o organizovaném násilí, Universum, Praha 1990. Kovtun J., Vilém Hejl, Zásada sporu, „Svědectvi““ 61, 1980.

Kratochvil A., Renesance historického románu, „České slovo (Mnichov)“2, 1980.

Novotný V., Ke kontextům kampanovského tématu, [in:] Zikmund Winter mezi historii a umèním, ed. V. Brožová, Okresní muzeum Rakovník a Ústav pro českou literaturu AV ČR, Rakovník 1999.

Petříček M., Detektivka jako nástroj satiry, „Literární noviny“ 26, 1993.

Rambousek O., Gruber L., Zpráva dokumentačni komise K 231, Vydali členové dokumentační komise K 231 v exilu, Toronto 1973.

Strnad J., Historia magistra vitae?, „Hlasy domova (Melbourne)“ 16, 1979.

Zelinský M., Vilém Hejl, [in:] Slovník české literatury po roce 1945, www.slovnikceskeliteratury.cz/ showContent.jsp?docId=739\&hl=HEJL + .

\section{The Role of Historical Memory in the Novels of Vilém Hejl}

Summary

The writer Vilém Hejl (1934-1989) wrote in the 1960s and 1970s three novels (Zásada sporu, Hodinah věz dopravcůa, Ex offo) which he published after leaving Czechoslovakia in 1978. In his prose, Hejl repeatedly thematized the role of memory in the formation of history, or sensitively perceived the discrepancy between collective memory and individual memory and the resulting problematic nature of the unified interpretation of history. This was especially at a time when history and memory were to serve as a tool to promote a certain interpretation of the past that would suit the interests of the ruling regime or its opponents.

Keywords: Vilém Hejl, Czech literature, state security, memory, the history of the 20th century, Czechoslovakia, exile

\section{Úloha historickej pämeti v románoch Viléma Hejla}

\section{Zhrnutie}

Spisovatel' Vilém Hejl (1934-1989) napísal v šest’desiatych a sedemdesiatych rokoch tri romány (Zásada sporu, Hodina hvězdopravců a Ex offo), ktoré vydal až po svojom odchodu z Československa v roku 1978 do exilu. Vo svojích prózach Hejl opakovane tematizoval úlohu pamäte na utváraní dejín, respektíve citlivo vnímal rozpor medzi pamätou kolektívnou a individuálnou a z toho plynúcu problematickost' jednotného výkladu histórie. A to najmä v čase, ked' by dejiny a pamät' mali slúžit' ako nástroj na presadenie určitého výkladu minulosti, ktorý by vyhovoval záujmom vládnuceho režimu, prípadne jeho odporcom.

Kl'účové slová: Vilém Hejl, česká literatura, Štátna bezpečnost', pamät', dejiny 20. storočia, Československo, exil 